\title{
The Effects of Asthma on the Stress Oxidative, Inflammation, and Endothelial Dysfunction Characteristics in Children with Severe Community- Acquired Pneumonia
}

\author{
Ali Arjmand Shabestari \\ Arak University of Medical Sciences \\ Pegah Mohaghegh \\ Arak University of Medical Sciences \\ Habibeh Kiyanrad \\ Arak University of Medical Sciences \\ Fatemeh Imanparast ( $\square$ fimaniran64@gmail.com ) \\ Arak University of Medical Sciences
}

\section{Research Article}

Keywords: Community-Acquired Pneumonia, Asthma, Oxidative stress, Inflammation, Endothelial dysfunction

Posted Date: December 9th, 2020

DOI: https://doi.org/10.21203/rs.3.rs-116563/v1

License: (9) This work is licensed under a Creative Commons Attribution 4.0 International License.

Read Full License 


\section{Abstract}

Background: Pulmonary vascular endothelial activation, inflammation, and stress oxidative have been implicated in adverse clinical outcomes of community-acquired pneumonia (CAP). Although chronic lung problems such as asthma may affect the consequences of pneumonia, the exact mechanism of this effect remains unclear. The present study aimed to assess the effects of asthma on the oxidative stress, inflammation, and endothelial dysfunction biomarkers in children pneumonia.

Methods: This cross-sectional study was performed at Amir Kabir Hospital affiliated to Arak University of Medical Sciences, Arak, Iran. Participants were 25 children with severe CAP and asthma (group I), 25 children with severe CAP (group II), and 25 healthy children (group III) with 2 to 6 years of age. Fasting blood samples were taken to the assay of serum malondialdehyde (MDA), total antioxidant capacity (TAC), tumor necrosis factor-alpha (TNF-a), soluble vascular cell adhesion molecule-1 (sVCAM-1), and Plasminogen activator inhibitor-1 (PAl-1).

Results: We observed a significant reduction in TAC in groups I and II $(0.997 \pm 0.22$ and $1.23 \pm 0.21 \mathrm{mmol} / \mathrm{l}$, respectively) compared with group III $(1.46 \pm 0.19 \mathrm{mmol} / \mathrm{l})$. This reduction was significantly higher in group I than in group II. Also, we observed a significant increase in MDA and TNF-a in groups I $(2.57 \pm 0.40$ $\mu \mathrm{mol} / \mathrm{l}, 6.94 \pm 1.61 \mathrm{pg} / \mathrm{ml}$, respectively) and II $(6.94 \pm 1.61 \mu \mathrm{mol} / \mathrm{l}, 5.54 \pm 1.84 \mathrm{pg} / \mathrm{ml}$, respectively) compared with group III ( $1.89 \pm 0.27 \mu \mathrm{mol} / \mathrm{l}, 3.42 \pm 1.32 \mathrm{pg} / \mathrm{ml}$, respectively). The increase in MDA was significantly higher in group I than in group II.

VCAM-1 and PAI-1 as endothelial dysfunction biomarkers increased significantly in group I (1.5 \pm 0.62 $\mathrm{mmol} / \mathrm{l}$ and $10.52 \pm 3.2 \mathrm{AU} / \mathrm{ml}$, respectively) compared with groups II $(1.06 \pm 0.53 \mathrm{mmol} / \mathrm{l}$ and $8.23 \pm 3.4$ $\mathrm{AU} / \mathrm{ml}$, respectively) and III (0.6 $\pm 0.35 \mathrm{mmol} / \mathrm{l}$ and $2.39 \pm 0.83 \mathrm{AU} / \mathrm{ml}$, respectively). Also, VCAM1 and PAI-1 increased significantly in group II compared with groups III.

Conclusions: Asthma can exacerbate the consequences of pneumonia in children by increasing oxidative stress, inflammation, and endothelial dysfunction.

\section{Background}

Pneumonia is an infection of the lungs caused by bacteria, viruses, fungi, and parasites that impose significant costs for the health care system and exhibit the most common reason for the death of infectious origin (1). In this disease, polymorphonuclear neutrophils and macrophages fight with microorganisms by using reactive oxygen species (ROSs) and lysosomal enzymes (2). As a consequence of pulmonary defense mechanism in inflammatory diseases such as pneumonia and asthma, Oxidative stress (OS) at the systemic level may have a central role with adverse clinical outcomes of these diseases, such as the endothelial dysfunction (ED), exacerbation of inflammation, and shortness of breath, and ultimately acute respiratory distress syndrome (ARDS), and death (3-5). 
ED causes pulmonary edema due to an increase in endothelial permeability. The activated endothelium mediates leukocyte binding to express the adhesion molecules such as vascular cell adhesion molecule-1 (VCAM-1) and intercellular adhesion molecule 1 (ICAM-1) that mediate leukocyte binding. Upon leukocyte binding, these adhesion molecules activate endothelial cell signal transduction and then alter endothelial cell shape for the opening of passageways, through which leukocytes can migrate (6-7).

Characterized by chronic inflammation in the airway wall (8), asthma is the most common chronic respiratory disease in children, which is prevalent in developing countries. Although it cannot be considered a direct cause of pneumonia, children with asthma are more prone to develop pneumonia due to previous lung damage. As a result, a child with asthma may have more severe symptoms and complications from pneumonia. Asthma may exacerbate the clinical consequences of pneumonia, such as ED (9-11).

We are not aware of any studies on assessing the changes in OS, inflammation, and ED biomarkers in children with asthma and pneumonia together compared with children with pneumonia only. Therefore, the current study assessed the alterations in OS, TNF- $\alpha$, and ED biomarkers in children with asthma and pneumonia, children with pneumonia only, and healthy children.

\section{Materials And Methods}

\section{Study design and participants}

A cross-sectional study was conducted at the Pediatric Clinic of Amirkabir Hospital in Arak, Iran, from January 2019 to September 2019. The present study aimed to assess the effects of asthma on the oxidative stress, inflammation, and endothelial dysfunction biomarkers in children pneumonia.

To estimate the sample size, we considered type $1(\alpha)$ and type 2 errors $(\beta)$ of 0.05 and 0.20 (power = $80 \%$ ), respectively, and serum MDA level as a key variable. Based on a previous study (12), SD ( $\sigma 1)$ of control MDA was $0.1 \mu \mathrm{mol} / \mathrm{L}, \mathrm{SD}(\sigma 2)$ of case MDA was $0.07 \mu \mathrm{mol} / \mathrm{L}$, and the difference in mean (d) of insulin levels was $0.15 \mu \mathrm{mol} / \mathrm{L}$. We reached the sample size of 9 participants for each group. The sample size of our study consisted of 25 children diagnosed with severe community-acquired pneumonia (sCAP), 25 patients diagnosed with asthma and SCAP, and 25 healthy children.

Pneumonia was defined as an acute pulmonary infiltrate evident on chest radiography with symptoms and signs of a lower respiratory tract infection: fever, cough, and purulent sputum. Pneumonia was confirmed with physical exams, microbiologic culture data, and Chest x-ray. CAP in children was defined as a lower respiratory tract infection in a child who has not resided in a hospital or health care facility in the preceding 14 days. CAP in children is one of the most common acute infections that require going to the hospital. Children with SCAP, due to respiratory distress, are not able to eat, drink, and alert. They also have undesirable hydration status and oxygenation status (13-14). 
The asthma of children was confirmed by a physician via the symptoms of recurrent coughing, wheezing, and chest tightness.

Exclusion criteria included children with severely smoking parents and severe or multiple systemic diseases.

\section{Ethics and consent}

The present study was ethically approved by the Committee on Human Research, Publication and Ethics (CHRPE) at Arak University of Medical Sciences, Arak, Iran (IR.ARAKMU.REC.1397.3001). Informed consent to participate in the study was obtained from parent of the children.

\section{Biochemical assessments:}

Blood samples of all the subjects were taken, and aliquot samples of serums were saved after centrifugation $(20 \mathrm{~min}, 3000 \mathrm{rpm})$ at $-80^{\circ} \mathrm{C}$.

According to the method of Benzie \& Strain in 1996 (15), TAC was analyzed using fluorescence recovery after photobleaching (FRAP) assay, which depends on the capacity of serum to reduce $\mathrm{Fe}^{3+}$ to $\mathrm{Fe}^{2+}$.

Serum MDA levels were determined by the thiobarbituric acid reactive substances test (TBARS) spectrophotometric test, as described by Santos in 1980 (16).

PAI-1 was measured as an indicator of ED by ELIZA kit (Germany, ZellBio, ZB-11159C-H9648). Also, VCAM-1, as another indicator of ED, was measured by the ELIZA kit (France, Diaclone SAS, 25020).

Serum TNF-a was measured through the ELISA method according to the manufacture's instruction (Biovendor, Germany, Cat $\neq$ RAF128R).

\section{Statistical analysis}

The Kolmogorov-Smirnov test was employed to assay the normal distribution of variables. The one-way ANOVA and Kruskal-Wallis test were employed to compare Anthropometric and Biochemical factors between groups. Post Hoc and Mann-Whitney tests were utilized to compare subgroups (I, II, III). All statistical analyses were performed using SPSS version 17 (SPSS, Chicago, IL, USA).

\section{Result}

This study was conducted from January 2019 to September 2019. It consisted of 25 children with pneumonia and asthma (group I), 25 children with pneumonia (group II), and 25 healthy children (group III) with 2 to 6 years of age.

Table 1 presents the children's anthropometric variables. 
Table 1

Anthropometric variables of the studied children

\begin{tabular}{|lllll|}
\hline Variable & $\begin{array}{l}\text { child with pneumonia and asthma } \\
\text { (group I) } \\
\mathbf{n = 2 5}\end{array}$ & $\begin{array}{l}\text { child with pneumonia } \\
\text { (group II) } \\
\mathbf{n}=\mathbf{2 5}\end{array}$ & $\begin{array}{l}\text { Control } \\
\text { (group III) }\end{array}$ & $\begin{array}{l}\mathbf{P} \\
\text { value } \\
\mathbf{n}=\mathbf{2 5}\end{array}$ \\
\hline $\begin{array}{l}\text { Sex } \\
(\mathrm{M} / \mathrm{F})\end{array}$ & $15 / 10$ & $13 / 12$ & $15 / 10$ & - \\
\hline $\begin{array}{l}\text { Age } \\
\text { (years) }\end{array}$ & $3.52 \pm 1.38$ & $3.08 \pm 1.32$ & $3.36 \pm$ & 0.493 \\
\hline $\begin{array}{l}\text { Weight } \\
(\mathrm{kg})\end{array}$ & $14.74 \pm 2.89$ & $14.19 \pm 3.46$ & 1.46 & \\
\hline $\begin{array}{l}\text { Height } \\
(\mathrm{cm})\end{array}$ & $97.46 \pm 12.19$ & & $14.46 \pm$ & 0.618 \\
\hline $\begin{array}{l}\text { BMI } \\
\left(\mathrm{kg} / \mathrm{m}^{2}\right)\end{array}$ & $14.90 \pm 1.49$ & $94.22 \pm 11.12$ & 3.59 & \\
\hline $\begin{array}{l}\text { Data are presented as mean value and standard deviation (SD); } * \mathrm{p}<0 \text { 05; Male/Female (M/F); Body } \\
\text { Mass Index (BMI); }\end{array}$ & $14.79 \pm 1.18$ & $\begin{array}{l}96.08 \pm \\
12.59\end{array}$ & 0.635 \\
\hline
\end{tabular}

Results showed a significant reduction in TAC in groups I and II $(0.997 \pm 0.22$ and $1.23 \pm 0.21 \mathrm{mmol} / \mathrm{l}$, respectively) compared with group III $(1.46 \pm 0.19 \mathrm{mmol} / \mathrm{I})$, which was higher in group I than in group II. Also, a major increase was observed in MDA and TNF-a in groups I $(2.57 \pm 0.40 \mu \mathrm{mol} / \mathrm{I}, 6.94 \pm 1.61 \mathrm{mmol} / \mathrm{l}$, respectively) and II ( $2.11 \pm 0.26 \mu \mathrm{mol} / \mathrm{I}, 5.54 \pm 1.84 \mathrm{mmol} / \mathrm{I}$, respectively) compared with group III $(1.89 \pm 0.27 \mu \mathrm{mol} / \mathrm{I}, 3.42 \pm 1.32 \mathrm{mmol} / \mathrm{I}$, respectively), which was significantly higher in group I than in group II (Table2). VCAM-1 and PAl-1 as ED biomarkers increased significantly in group I (1.5. $\pm 0.62 \mathrm{mmol} / \mathrm{I}$ and $10.52 \pm 3.2 \mathrm{AU} / \mathrm{ml}$, respectively) compared with groups II $(1.06 \pm 0.53 \mathrm{mmol} / \mathrm{l}$ and $8.23 \pm 3.4 \mathrm{AU} / \mathrm{ml}$, respectively) and III (0.6 $\pm 0.35 \mathrm{mmol} / \mathrm{I}$ and $2.39 \pm 0.83 \mathrm{AU} / \mathrm{ml}$, respectively). VCAM-1 and PAl-1 increased significantly in group II compared with groups III (Table2). 
Table 2

Biochemical parameters in control, child with pneumonia, and child with pneumonia and asthma

\begin{tabular}{|c|c|c|c|c|}
\hline \multirow[t]{2}{*}{ Variable } & $\begin{array}{l}\text { child with pneumonia and } \\
\text { asthma (group I) }\end{array}$ & $\begin{array}{l}\text { child with pneumonia } \\
\text { (group II) }\end{array}$ & $\begin{array}{l}\text { Control } \\
\text { (group III) }\end{array}$ & $P$ value \\
\hline & $n=25$ & $n=25$ & $n=25$ & \\
\hline \multirow{4}{*}{$\begin{array}{l}\text { TAC } \\
(\mathrm{mmol} / \mathrm{l})\end{array}$} & $0.997 \pm 0.22$ & $1.23 \pm 0.21$ & $1.46 \pm 0.19$ & 0.000 \\
\hline & & & & $\begin{array}{l}|\times| \mid: \\
0.001\end{array}$ \\
\hline & & & & $\begin{array}{l}|\times|||: \\
0.000\end{array}$ \\
\hline & & & & $\begin{array}{l}\|\times\| \| l: \\
0.001\end{array}$ \\
\hline \multirow{4}{*}{$\begin{array}{l}\text { MDA } \\
(\mu \mathrm{mol} / \mathrm{I})\end{array}$} & $2.57 \pm 0.40$ & $2.11 \pm 0.26$ & $1.89 \pm 0.27$ & 0.000 \\
\hline & & & & $\begin{array}{l}|\times| \mid: \\
0.000\end{array}$ \\
\hline & & & & $\begin{array}{l}|\times|||: \\
0.000\end{array}$ \\
\hline & & & & $\begin{array}{l}\|\times\| \mathrm{II}: \\
0.006\end{array}$ \\
\hline \multirow{4}{*}{$\begin{array}{l}\text { TNF-a } \\
(\mathrm{pg} / \mathrm{ml})\end{array}$} & $6.94 \pm 1.61$ & $5.54 \pm 1.84$ & $3.42 \pm 1.32$ & 0.000 \\
\hline & & & & $\begin{array}{l}|\times| \mid: \\
0.011\end{array}$ \\
\hline & & & & $\begin{array}{l}|\times|||: \\
0.000\end{array}$ \\
\hline & & & & $\begin{array}{l}\|\times\| \|: \\
0.001\end{array}$ \\
\hline \multirow{3}{*}{$\begin{array}{l}\text { VCAM-1 } \\
(\mathrm{mmol} / \mathrm{l})\end{array}$} & $1.5 \pm 0.62$ & $1.06 \pm 0.53$ & $0.6 . \pm 0.35$ & 0.000 \\
\hline & & & & $\begin{array}{l}|\times| \mid: \\
0.009\end{array}$ \\
\hline & & & & $\begin{array}{l}|\times|||: \\
0.000\end{array}$ \\
\hline
\end{tabular}

Data are presented as mean value and standard deviation (SD); $* \mathrm{p}<0$ 05. Malondialdehyde (MDA); Total antioxidant capacity (TAC); Vascular cell adhesion molecule 1 (VCAM-1); plasminogen activator inhibitor-1 (PAI-1). Tumor necrosis factor alpha (TNF-a). P- value: Differences in the percentage changes on mean value of initial reading between groups I, II, and III. 


\begin{tabular}{|c|c|c|c|c|}
\hline \multirow[t]{3}{*}{ Variable } & $\begin{array}{l}\text { child with pneumonia and } \\
\text { asthma (group I) }\end{array}$ & $\begin{array}{l}\text { child with pneumonia } \\
\text { (group II) }\end{array}$ & $\begin{array}{l}\text { Control } \\
\text { (group III) }\end{array}$ & $P$ value \\
\hline & $n=25$ & $n=25$ & $n=25$ & \\
\hline & & & & $\begin{array}{l}\| \times \text { × } \|: \\
0.000\end{array}$ \\
\hline \multirow{4}{*}{$\begin{array}{l}\text { PAI-I } \\
(\text { AU/ml) }\end{array}$} & $10.52 \pm 3.2$ & $8.23 \pm 3.4$ & $2.39 \pm 0.83$ & 0.000 \\
\hline & & & & $\begin{array}{l}|\times| \mid: \\
0.017\end{array}$ \\
\hline & & & & $\begin{array}{l}|\times||| \mid: \\
0.000\end{array}$ \\
\hline & & & & $\begin{array}{l}\|\times\| \text { II: } \\
0.000\end{array}$ \\
\hline \multicolumn{5}{|c|}{$\begin{array}{l}\text { Data are presented as mean value and standard deviation (SD); } * \mathrm{p}<0 \quad 05 \text {. Malondialdehyde (MDA); } \\
\text { Total antioxidant capacity (TAC); Vascular cell adhesion molecule } 1(\mathrm{VCAM}-1) \text {; plasminogen activator } \\
\text { inhibitor- } 1 \text { (PAl-1). Tumor necrosis factor alpha (TNF-a). P-value: Differences in the percentage } \\
\text { changes on mean value of initial reading between groups I, II, and III. }\end{array}$} \\
\hline
\end{tabular}

\section{Discussion}

In this study, we observed that in children with SCAP, biomarkers of OS, inflammation, and ED were significantly higher than healthy children, and it is also higher in asthmatic children with pneumonia than in non-asthmatic children. This is probably because asthma may exacerbate OS and inflammation in children with pneumonia.

Studies have shown the interaction between pneumonia and cardiovascular diseases (CVDs). According to the cohort study of Yeh et al. 2019, patients with CVDs had a higher risk of CAP, and conversely, CVDs risk was intensified with CAP. In recent years, CVDs were considered as an outcome of patients admitted to hospital with pneumonia infection (17). After recovery of CAP in addition to the period of the acute infection, there is still the risk of acute cardiovascular events due to systematic inflammation (18).

The initial stage of molecular and cellular stages leading to CVDs is ED (19-20). OS and inflammation are the two main causes of its creation (21-22).

Studies indicate the underlying respiratory diseases such as asthma may be effective in the severity of pneumonia injuries. Asthma, whose main feature is chronic inflammation in the airway wall (8), is the most common chronic respiratory disease in children, especially in developing countries.

In this study, TNF- $a$ was significantly higher in children with pneumonia and asthma than pneumonia and healthy children. Studies indicate the inflammatory process associated with ED exacerbates the severity of the consequences of CAP (23). Also, recent evidence suggests a critical role for pneumonia infection in 
the pathogenesis of atherosclerosis by exacerbating OS, inflammation, and ED. Increasing the proinflammatory cytokine TNF- $a$ as a consequence of pneumonia induce ED by various mechanisms, such as increasing the endothelial permeability and reducing the endothelium-dependent relaxation. It increased vascular endothelial growth factor (VEGF) as the endothelial permeability mediator and diminishing the half-life of mRNA encoding for endothelial nitric oxide synthase and decreasing nitric oxide production $(24,25)$.

In this study, VCAM-1 and PAI-I as two biomarkers of ED were significantly higher in children with pneumonia and asthma than the children with pneumonia only. Also, they were significantly more in children with pneumonia than healthy children. OS and inflammation are closely linked with each other. Inflammatory mediators lead to OS, and reciprocally, OS increases the production of inflammatory mediators with the activation of NF-kB and AP-1 (26). NF-KB and AP-1 are involved in the activation of pro-inflammatory molecules, such as VCAM-1 and PAI-I (27).

In 2015, Lin et al. indicated that TNF-a-induced VCAM-1 expression in human cardiac fibroblasts was mediated by the activation of NF-KB by c-Src-mediated transactivation of the EGF receptor (EGFR)/PI3K/Akt cascade (28). ROSs regulate several cells signaling pathways, such as expression of VCAM-1, resulting in the release of inflammatory mediators (29).

Zhang et al. (2018) reported an increase in MDA and TNF- $a$ and a decrease TAC in CAP (30). Pikuza et al. (2012) reported an evaluation of the content of MDA as the lipid peroxidation indicator with decreasing of antioxidant activity in CAP patients (31). Majewska et al. (2004) ascertained OS development in the lungs at CAP patients (32). Muravlyova et al. (2016) showed that SCAP patients have more levels of oxidative proteins and MDA in erythrocytes than moderate CAP and healthy volunteers (33).

ROSs concentration and time of exposure are two determining factors in the effects of OS in the airway as well as in other organs. Due to damage in biomolecules and inducing intracellular signaling pathways by ROSs, more concentration and longer exposure of ROSs can lead to cell death by apoptosis (34). Accordingly, studies show that the attenuation of OS alleviates the organ damage.

Zhang et al. in 2018 demonstrated the treatment of CAP patients with $\mathrm{N}$-acetylcysteine (NAC) reduces MDA and increases TAC compared with those in the non-NAC group (30). In asthma as a chronic inflammatory airway disease, OS exacerbates airway inflammation by inducing various pro-inflammatory moderators, boosting bronchial hyperresponsiveness, exciting bronchospasm, and increasing mucin secretion (35).

\section{Conclusions}

Significant changes in OS, inflammation, and ED biomarkers occur in asthma children with pneumonia compared with pneumonia children without asthma and healthy children. Our findings amplify the growing evidence supporting the concept that endothelial activation, inflammation, and OS play an 
important mechanistic role of effects asthma in the pathogenesis of pneumonia. Treatment with antioxidants and anti- VCAM-1 pharmacological agents may help reduce outcomes in these children.

\section{Abbreviations}

Community-acquired pneumonia (CAP); Malondialdehyde (MDA); Total antioxidant capacity (TAC); Tumor necrosis factor-alpha (TNF-a); Soluble vascular cell adhesion molecule-1 (sVCAM-1); Plasminogen activator inhibitor-1 (PAI-1); Reactive oxygen species (ROSs); Oxidative stress (OS); Endothelial dysfunction (ED); Acute respiratory distress syndrome (ARDS); Intercellular adhesion molecule 1 (ICAM1); Fluorescence recovery after photobleaching (FRAP); Thiobarbituric acid reactive substances test (TBARS); Vascular endothelial growth factor (VEGF); N-acetylcysteine (NAC);

\section{Declarations}

\section{Acknowledgments}

The authors deeply thank all parents and their children who participated in the present study.

\section{Authors' contributions}

$\mathrm{FI}$ and AAS designed the experiment and supervised the project. $\mathrm{FI}, \mathrm{AAS}$, and HK performed the experiments and conducted the lab work. PM conducted the statistical analysis. FI and AAS wrote the paper. All authors read and approved the final manuscript.

\section{Author's information}

Not applicable

\section{Funding}

This study was supported by Arak University of Medical Sciences, Arak, Iran (grant number 3001).

\section{Availability of data and materials}

All data used in the current study are available from the corresponding author on reasonable request.

\section{Ethics approval and consent to participate}

\section{All the experiment protocol for involving humans in this study was in accordance to guidelines of national/international/institutional or Declaration of Helsinki.}

The present study was ethically approved by the Committee on Human Research, Publication and Ethics (CHRPE) at Arak University of Medical Sciences, Arak, Iran (IR.ARAKMU.REC.1397.3001). Informed consent to participate in the study was obtained from parent of the children. 


\section{Consent for publication}

Not applicable

\section{Competing interests}

The authors declare that they have no competing interests.

\section{References}

1. José RJ, Periselneris JN, Brown JS. Opportunistic bacterial, viral and fungal infections of the lung. Medicine (Abingdon). 2020; 48(6): 366-372.

2. Paiva CN, Bozza MT. Are Reactive Oxygen Species Always Detrimental to Pathogens? Antioxid Redox Signal. 2014; 20(6): 1000-1037.

3. Ciencewicki J, Trivedi S, Kleeberger SR. Oxidants and the pathogenesis of lung diseases. J Allergy Clin Immunol. 2008; 122(3): 456-470.

4. Matthay MA, Zemans RL, Zimmerman GA, Arabi YM, Beitler JR, Mercat A, Herridge M, Randolph AG, Calfee CS. Acute respiratory distress syndrome. Nat Rev Dis Primers. 2019; 5(1): 18.

5. Maniatis NA, Kotanidou A, Catravas JD, Orfanosa SE. Endothelial pathomechanisms in acute lung injury. Vascul Pharmacol. 2008; 49(4): 119-133.

6. Uhlig S, Yanga Y, Waade J, Claudia Wittenberg C, Babendreyer A, Kueblerb WM. Differential Regulation of Lung Endothelial Permeability in Vitro and in Situ. Cell Physiol Biochem 2014; 34:119.

7. Cook-Mills JM, Marchese ME, Abdala-ValenciaVascular H. Cell Adhesion Molecule-1 Expression and Signaling During Disease: Regulation by Reactive Oxygen Species and Antioxidants. Antioxid Redox Signal. 2011; 15(6): 1607-1638.

8. Jesenak M, Zelieskova M, Babusikova E. Oxidative Stress and Bronchial Asthma in Children-Causes or Consequences. Front. Pediatr. 2017;5: 8 pages.

9. Abbey Ryan. What is the link between asthma and pneumonia? 2019. https://www.medicalnewstoday.com/articles/325312

10. Nantanda R, Tumwine JK, Ndeezi G, Ostergaard MS. Asthma and Pneumonia among Children Less Than Five Years with Acute Respiratory Symptoms in Mulago Hospital, Uganda: Evidence of UnderDiagnosis of Asthma. PLoS One. 2013; 8(11): e81562.

11. Green CE, Turner AM. The role of the endothelium in asthma and chronic obstructive pulmonary disease (COPD). Respir. Res. 2017; 18: 1-14.

12. Muravlyova L, Molotov-Luchankiy V, Bakirova R, Klyuyev D, Demidchik L, Lee V. Characteristic of the Oxidative Stress in Blood of Patients in Dependence of Community-Acquired Pneumonia Severity. Maced J Med Sci. 2016; 4(1):122-127.

13. Davies HD, Community-acquired pneumonia in children. Paed Child Health. 2003; 8(10): 616-619. 
14. Brown JS, Community-acquired pneumonia. Clin Med (Lond). 2012; 12(6): 538-543.

15. Benzie I, Strain J. The Ferric Reducing Ability of Plasma (FRAP) as a Measure of "Antioxidant Power: The FRAP Assay". Anal. Biochem. 1996. 239, 70-76.

16. Santos MT, Valles J, Aznar J, Vilches J. Determination of plasma malondialdehyde-like material and its clinical application in stroke patients. J Clin Pathol. 1980; 33(10): 973-976.

17. Violi F, Cangemi R, Falcone M, Taliani G, Pieralli F, Vannucchi V, Nozzoli C, Venditti M, Chirinos JA, Corrales-Medina VF.Cardiovascular Complications and Short-term Mortality Risk in CommunityAcquired Pneumonia.Clin Infect Dis. 2017; 64(11):1486-1493.

18. Singanayagam A, Elder DHJ, Chalmers JD. Is community-acquired pneumonia an independent risk factor for cardiovascular disease? Eur Respir J. 2012; 39: 187-196

19. Sun HJ, Wu ZY, Nie ZW, Bian JS. Role of Endothelial Dysfunction in Cardiovascular Diseases: The Link Between Inflammation and Hydrogen Sulfide. Front. Pharmacol, 2019; 10: 1568.

20. Barthelmes J, Nägele MP, Ludovici V, Ruschitzka F, Sudano I, Flammer AJ. Endothelial dysfunction in cardiovascular disease and Flammer syndrome-similarities and differences. EPMA J. 2017; 8(2): 99-109.

21. de Dios ST, Sobey CG, Drummond GR. Oxidative stress and endothelial dysfunction. Endothelial Dysfunction and Inflammation.2010: 37-64

22. Budhiraja R, Tuder RM, Hassoun PM. Endothelial Dysfunction in Pulmonary Hypertension. Circulation. 2004; 109:159-165.

23. Luciano-González A, Suárez-Cuenca JA, Melchor-López A, Santiago- Córdova JL. Impact of the inflammatory process associated with endothelial dysfunction in the severity of community-acquired pneumonia. Med Int Mex 2016; 32 (5)

24. Maloney JP, Gao L. Proinflammatory Cytokines Increase Vascular Endothelial Growth Factor Expression in Alveolar Epithelial Cells. Mediat Inflamm. 2015,2015: 7 pages

25. Stenvinkel P. Endothelial dysfunction and inflammation-is there a link? Nephrol Dial Transplant. 2001; 16: 1968-1971.

26. Rahman I, MacNee W Oxidative stress and regulation of glutathione in lung inflammation. Eur Respir J. 2000; 16(3):534-54.

27. Mukhopadhyay S, Hoidal JR, Mukherjee TK. Role of TNFa in pulmonary pathophysiology. Respir Res. $2006,7: 125$

28. Lin CC, Pan CS, Wang CY, Liu SW, Hsiao LD, Yang CM. Tumor necrosis factor-alpha induces VCAM-1mediated inflammation via c-Src-dependent transactivation of EGF receptors in human cardiac fibroblasts. J Biomed Sci. 2015; 22(1): 53.

29. Chen Y, Luo G, Yuan J, Wang Y, Yang X, Wang X, Li G, Liu Z, Zhong N. Vitamin C mitigates oxidative stress and tumor necrosis factor-alpha in severe community-acquired pneumonia and LPS-induced macrophages.Mediators Inflamm. 2014; 2014: 426740. 
30. Zhang Q, Ju Y, Ma Y, Wang T. PN-acetylcysteine improves oxidative stress and inflammatory response in patients with community acquired pneumonia.A randomized controlled trial.Medicine. 2018; 97(45): e13087.

31. Pikuza OI, Zakirova AM, Rashitov LF, et al. Lipid peroxidation and serum zinc status of communityacquired pneumonia among schoolchildren. Pediatrics. 2012; 91:30-32.

32. Majewska E, Kasielski M, Luczynski R, Bartosz G, Bialasiewicz P, Nowak D Elevated exhalation of hydrogen peroxide and thiobarbituric acid reactive substances in patients with community acquired pneumonia. Respir Med. 2004; 98(7):669-76.

33. Muravlyova L, Molotov-Luchankiy V, Bakirova R, Klyuyev D, Demidchik L, Lee V. Characteristic of the Oxidative Stress in Blood of Patients in Dependence of Community-Acquired Pneumonia Severity. Maced J Med Sci. 2016; 4(1): 122-127.

34. Valko M, Leibfritz D, Moncol J, Cronin MT, Mazur M, Telser J. Free radicals and antioxidants in normal physiological functions and human disease. Int J Biochem Cell Biol. 2007; 39(1):44-84.

35. Cho SY, Moon HB. The Role of Oxidative Stress in the Pathogenesis of Asthma. Allergy Asthma Immunol Res. 2010; 2(3): 183-187. 